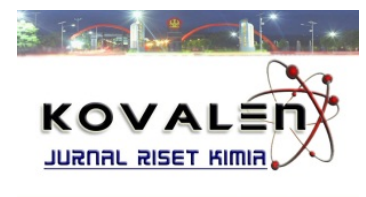

\title{
DERAJAT DEASETILASI KITOSAN DARI CANGKANG KERANG DARAH DENGAN PENAMBAHAN NaOH SECARA BERTAHAP
}

\section{[Chitosan Deacetilation Degree from Anadara granosa by Gradually Adding $\mathrm{NaOH}]$}

\author{
Syaiful Bahri ${ }^{1^{*}}$, Erwin Abd. Rahim ${ }^{1)}$, Syarifuddin ${ }^{1)}$ \\ 1) Jurusan Kimia FMIPA Universitas Tadulako, Palu
}

Diterima 30 Agustus 2015, Disetujui 22 September 2015

\begin{abstract}
The study about raising of chitosan deacetilation degree in Anadara granosa by gradually adding $\mathrm{NaOH}$ has been done. The aim of the research was to study the influence of gradually added $\mathrm{NaOH}$ on the raising of chitosan deacetilation. The degree of chitosan deacetilation was determined by using spectroscopy of Fourier Transform Infra Red (FTIR). The result showed that the deacetilation degree increase with the increase of $\mathrm{NaOH}$ added i.e 79\%; 85,9\%; 89,95\% for the first, the second and the third addition of $\mathrm{NaOH}$ with 3, 6 and 9 hours of the reaction the respectively.
\end{abstract}

Keywords: Anadaragranosa; Chitin; Deacetilation Degree; Chitosan

\begin{abstract}
ABSTRAK
Telah dilakukan penelitian peningkatan derajat deasetilasi kitosan Anadaragranosa dengan penambahan $\mathrm{NaOH}$ secara bertahap. Tujuan penelitian ini untuk mengeahui pengaruh penambahan $\mathrm{NaOH}$ secara bertahap terhadap peningkatan derajat deasetilasi kitosan. Derajat deasetilasi kitosan ditentukan dengan menggunakan spektroskopi Fourier Transform Infra Red (FTIR). Hasil penelitian menunjukkan bahwa derajat deasetilasi meningkat seiring dengan peningkatan penambahan $\mathrm{NaOH}$ yaitu dengan 1 kali penambahan $\mathrm{NaOH}$ dalam waktu 3 jam menghasilkan deraja deasetilasi $79 \%, 2$ kali penambahan $\mathrm{NaOH}$ dalam waktu 6 jam menghasilkan derajat deasetilasi 85,9\% dan 3 kali penambahan $\mathrm{NaOH}$ dalam waktu 9 jam menghasilkan derajat deasetilasi sebesar 89,95\%. Dengan demikian penambahan $\mathrm{NaOH}$ secara bertahap dapat meningkatan derajat deasetilasi.

Kata Kunci: Anadaragranosa, Kitin, Derajat Deasetilasi, Kitosan.
\end{abstract}




\section{LATAR BELAKANG}

Kerang darah (Anadara granosa) merupakan jenis kerang yang banyak dimanfaatkan sebagai makanan pengganti lauk di Indonesia. Kelimpahan kerang darah (Anadara granosa) di Indonesia menurut Direktorat Jendral Perikanan Tangkap Indonesia (2012) yaitu 48,994 ton/tahun. Dinas Perikanan dan Kelautan Provinsi Riau (2012) menyatakan bahwa Provinsi Riau menghasilkan kerang sebanyak 34,388 ton/tahun sedangkan data dari dinas perikanan Sulawesi Tengah tahun 2012 sebanyak 3 ton/Tahun. Daging kerang darah oleh masyarakat Sulawesi Tengah khususnya Kabupaten Morowali, banyak dikonsumsi atau diolah sebagai makanan pengganti lauk pauk, sehingga sisa cangkang kerang darah tersebut menjadi limbah Margonof, 2003 dalam Sinardi dkk, 2013 menyatakan bahwa kandungan kitin pada cangkang kerang berkisar $14-35 \%$.

Kitosan adalah senyawa poli-(2amino-2-deoksi- $\beta$-(1-4)-D-glukopiranosa) dengan rumus molekul $\left(\mathrm{C}_{6} \mathrm{H}_{11} \mathrm{NO}_{4}\right)_{\mathrm{n}}$ merupakan biopolimer yang sumbernya melimpah serta merupakan padatan amorf yang berwarna putih kekuningan dan bersifat nontoksit dan biodegradable. Kitosan tidak dapat larut dalam larutan netral atau basa tetapi larut dalam asamasam organik. Kitosan banyak dimanfaatkan dalam berbagai bidang yaitu:
1. Bidang pertanian, tanaman yang diperlakukan dengan kitosan memiliki ketahanan yang baik terhadap serangan jamur.

2. Bidang kesehatan, kitosan bermanfaat dalam program diet karena kemampuannya menurunkan jumlah kolesterol, antikoagulan dalam darah serta digunakan sebagai agen antibakteri.

3. Bidang bioteknologi memanfaatkan kitosan sebagai zat yang berperan dalam imobilisasi enzim, pemisahan protein, dan regenerasi sel.

4. Industri makanan, kitosan digunakan sebagai antioksidan, pengawet alami penyerap zat warna dan pengemulsi. Kitosan juga dimanfaatkan sebagai bioadsorben/pengkhelat logam.

Mutu kitosan dipengaruhi oleh derajat deasetilasi yang merupakan salah satu karakteristik kimia yang paling penting. Derajat deasetilasi kitosan ditentukan oleh beberapa faktor yaitu konsentrasi $\mathrm{NaOH}$, suhu dan lama proses deasetilasinya (Prasetyo, 2004). Hasil penelitian Sianardi, 2013 pada kitin kerang hijau menggunakan $\mathrm{NaOH} 45 \%$ dengan suhu pemanasan pada $140^{\circ} \mathrm{C}$ diperoleh derajat deasetilasi sebesar 38,91\%. Sedangkan Ramadhan dkk, 2010 menyatakan bahwa Derajat Deasetilasi kitosan sebesar 100\% dari limbah cangkang udang, dengan metode Deasetilasi bertahap 


\section{METODE PENELITIAN}

\section{Bahan dan Peralatan}

Bahan dasar yang digunakan dalam penalitian ini adalah Cangkang Kerang Darah, $\mathrm{NaOH}, \mathrm{HCl} 1 \mathrm{M}, \mathrm{NaOCl} 4 \%$, Aquadest,

Peralatan yang digunakan dalam penelitian ini adalah neraca analitik, hot plate, 1 set alat refluks, oven, FTIR, dan alat-alat gelas yang umum digunakan dalam laboratorium

\section{Prosedur Kerja}

\section{Persiapan}

Persiapan dimulai dengan mencuci limbah cangkang kerang darah dengan air berulang kali. Cangkang dijemur dengan sampai benar-benar kering. kemudian dihaluskan dengan belender elektrik dan diayak dengan ayakan 60 mesh. Serbuk cangkang kerang darah yang lolos ayakan 60 mesh dikeringkan dengan oven pada suhu $60^{\circ} \mathrm{C}$ selama 6 jam.

\section{Deproteinasi}

Campuran dipanaskan pada suhu $80^{\circ} \mathrm{C}$ selama 1 jam. Setelah itu dinetralkan $\mathrm{pH}$ dengan aquadest dengan cara dicuci dan disaring. Kemudian dikeringkan dalam oven pada suhu $60^{\circ} \mathrm{C}$.

\section{Demineralisasi}

Kitin yang telah di deproteinasi selanjutnya dilakukan proses demineralisasi dengan $\mathrm{HCl} 1 \mathrm{M}$ dengan perbandingan 1:15 sambil diaduk selama 3 jam. Campuran disaring dan residu dicuci dengan aquadest sampai $\mathrm{pH}$ netral kemudian selanjutnya dikeringkan dengan oven pada suhu $60^{\circ} \mathrm{C}$.Proses berikutnya ialah menghilangkan mineral-mineral yang mungkin terdapat dalam cangkang kerang darah, seperti kalsium, magnesium dan fosfor. Dimineralisasi dilakukan dengan melarutkan 10 gram dari hasil deproteinasi dengan $150 \mathrm{ml} \mathrm{HCl} 1 \mathrm{M}$ Perbandingan 1:15. Mengaduk selama 3 jam pada suhu kamar. Setelah itu mencuci larutan dengan cara dekantir menggunakan akuades sampai $\mathrm{pH}$ netral. Kemudian menyaring dan mengeringkan endapan dalam oven pada suhu $60^{\circ} \mathrm{C}$ sampai kering.

\section{Depigmentasi}

Residu kitin hasil demineralisasi dilakukan proses depigmentasi dengan $\mathrm{NaOCl} \quad 4 \%$ (1:10). Campuran diaduk selama 1 jam. Lalu disaring kemudian dicuci dengan aquadest sampai $\mathrm{pH}$ netral dan disaring. Setelah itu residu dikeringkan dalam oven pada suhu $60^{\circ} \mathrm{C}$.

\section{Deasetilasi}

Kitin yang diperoleh dari tahapan diatas dilanjutkan dengan proses deasetilasi dengan $\mathrm{NaOH} 60 \%$ dengan perbandingan 1:15 (b/v) pada temperatur $120^{\circ} \mathrm{C}$ dan variasi waktu reaksi $1 \times 3$ jam, $2 \times 3$ jam, dan $3 \times 3$ jam. Setiap tahapan regenerasi $\mathrm{NaOH}$ dalam reaksi deasetilasi $\mathrm{NaOH}$ baru, residu hasil deasetilasi disaring dan dicuci menggunakan akuades hingga $\mathrm{pH}$ netral. Selanjutnya hasil deasetilasi dianalisis menggunakan FTIR untuk menentukan derajat deasetilasi. 


\section{HASIL DAN PEMBAHASAN}

\section{Hasil isolasi kitin dari cangkang kerang darah}

$\begin{array}{lll}\text { Isolasi kitin dari cangkang } & \text { kerang } \\ \text { darah dilakukan melalui } & \text { proses } \\ \text { deproteinasi yang } & \text { merupakan } & \text { proses } \\ \text { penghilangan } & \text { protein } & \text { dengan }\end{array}$
menggunakan pelarut yang bersifat basa yaitu $\mathrm{NaOH}$ 4\%. Hasil deproteinasi dilanjutkan dengan proses demineralisasi untuk penghilangan mineral yang terkandung menggunakan pelarut $\mathrm{HCl}$. Menurut Arif (2006), bahwa kandungan mineral yang terdapat dalam hewan moluska yang terbanyak adalah $\mathrm{CaCO}_{3}$ dan $\mathrm{Ca}_{3}\left(\mathrm{PO}_{4}\right)_{2}$. Proses demineralisasi dengan $\mathrm{HCl}$ akan menghasilkan reaksi sebagai berikut:

$$
\begin{aligned}
& \mathrm{CaCO}_{3(\mathrm{~s})}+2 \mathrm{HCl}_{(\mathrm{l})} \longrightarrow \mathrm{CaCl}_{2(\mathrm{l})}+\mathrm{H}_{2} \mathrm{O}_{(\mathrm{l})}+\mathrm{CO}_{2(\mathrm{~g})} \\
& \mathrm{Ca}_{3}\left(\mathrm{PO}_{4}\right)_{2(\mathrm{~s})}+6 \mathrm{HCl}_{(\mathrm{l})} \longrightarrow 3 \mathrm{CaCl}_{2(\mathrm{l})}+2 \mathrm{H}_{3} \mathrm{PO}_{4(1)}
\end{aligned}
$$

Proses demineralisasi akan menghasilkan gas $\mathrm{CO}_{2}$. Hal ini dapat dilihat dari terbentuknya gelembung udara selama proses berlangsung. Dalam proses depigmentasi menggunakan $\mathrm{NaOCl}$ terjadi perubahan warna pada kitin dari kecoklatan menjadi putih kecoklatan. Menurut Arif (2006) bahwa penambahan $\mathrm{NaOCl}$ akan menyebabkan senyawa karotenoid yang terdapat pada kitin akan larut sehingga terjadi perubahan warna residu dari coklat menjadi putih.

Kitosan yang diperoleh dari pengolahan kitin pada setiap penambahan $\mathrm{NaOH}$ di analisis dengan menggunakan spektroskopi Infra Red Transformasi fourier (FTIR). Hasil analisis FTIR pada perlakuan 1x3 jam dengan 1kali penambahan $\mathrm{NaOH}$ dapat dilihat pada Gambar 1.

Ukuran partikel dari bahan yang digunakan akan sangat berpengaruh dalam proses ekstraksi, yang pada akhirnya akan meningkatkan jumlah lignin dan hemiselulosa yang terbebaskan. Dalam penelitian ini menggunakan jerami padi dengan ukuran partikel 60 mesh. Ekstraksi selulosa memberikan hasil seperti pada tabel berikut:

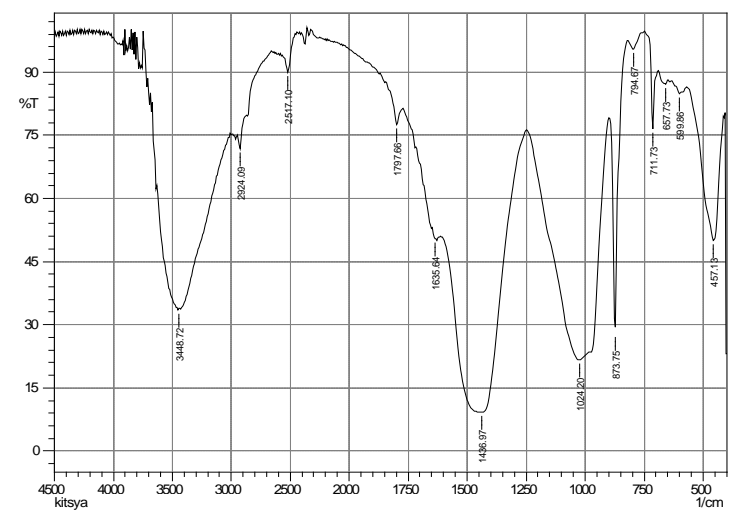

Gambar 1 Hasil analisis FTIR kitosan 1 tahap penambahan $\mathrm{NaOH}$ (3 jam)

Pada Gambar 1 terlihat adanya pita serapan pada bilangan gelombang $3448.72 \mathrm{~cm}^{-1}$ yang menunjukkan gugus fungsi $\mathrm{OH}$ ulur dan $\mathrm{NH}$ ulur. Pita serapan pada bilangan gelombang $2924.09 \mathrm{~cm}^{-1}$ menunjukkan gugus fungsi $\mathrm{CH}_{2}$ ulur, pita serapan pada bilangan gelombang $1635.64 \mathrm{~cm}^{-1}$ menunjukkan adanya gugus $\mathrm{C}=\mathrm{O}$ amida, pita serapan pada bilangan gelombang $1024.20 \mathrm{~cm}^{-1}$ menunjukkan adanya gugus fungsi $\mathrm{C}-\mathrm{O}-\mathrm{C}$ dan pada pita serapan pada bilangan gelombang 873.75 
$\mathrm{cm}^{-1}$ menunjukkan masih adanya mineral silika. Untuk hasil analisis spektroscopi infra read Pada perlakuan 2x3 jam dengan 2 kali penambahan $\mathrm{NaOH}$ yaitu dapat dilihat pada Gambar 2.

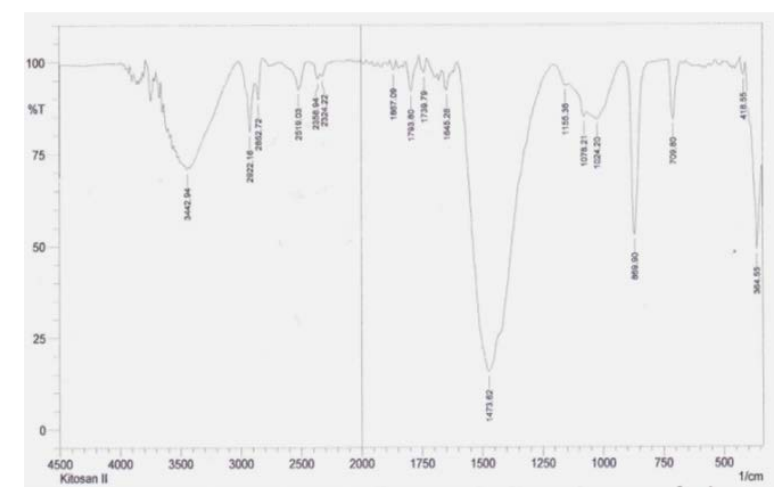

Gambar 2 Hasil FTIR kitosan dengan 2 tahap penambahan $\mathrm{NaOH}$ (6 Jam)

Pada Gambar 2 terlihat adanya pita serapan pada bilangan gelombang $3442.94 \mathrm{~cm}^{-1}$ yang menunjukkan gugus fungsi $\mathrm{OH}$ ulur dan $\mathrm{NH}$ ulur. Pita serapan pada bilangan gelombang 2922.16 $2852.72 \mathrm{~cm}^{-1}$ menunjukkan adanya gugus fungsi $\mathrm{CH}_{2}$ ulur, pita serapan pada bilangan gelombang $1645.26 \mathrm{~cm}^{-1}$ menunjukkan adanya gugus fungsi $\mathrm{C}=\mathrm{O}$ amida, pita serapan pada bilangan gelombang $1155.36-1024.20 \mathrm{~cm}^{-1}$ menunjukkan adanya gugs fungsi C-O-C, dan pita serapan pada bilangan gelombang $869.90 \mathrm{~cm}^{-1}$ menunjukkan masih adanya mineral silika. Dan Untuk hasil analisis spektroscopi infra read Pada perlakuan $3 \times 3$ jam dengan 3 kali penambahan $\mathrm{NaOH}$ yaitu dapat dilihat pada Gambar 3

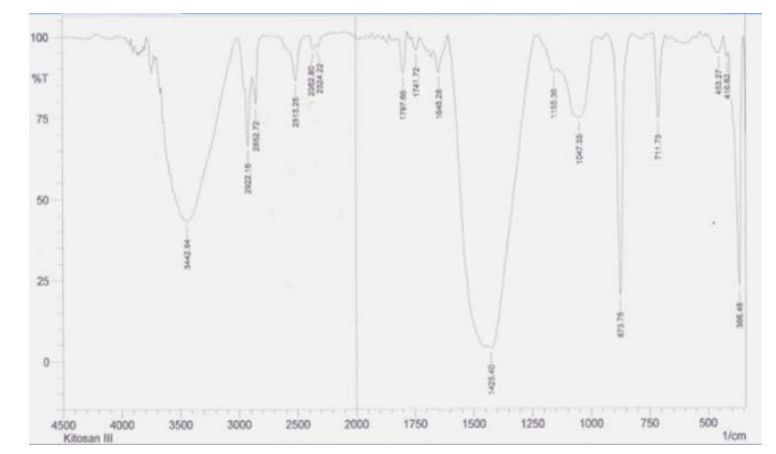

Gambar 3 Hasil FTIR kitosan dengan 3 tahap penambahan $\mathrm{NaOH}$ (9 Jam).

Pada Gambar 3 terlihat adanya pita serapan pada bilangan gelombang $3442.94 \mathrm{~cm}^{-1}$ yang menunjukkan gugus fungsi $\mathrm{OH}$ ulur dan $\mathrm{NH}$ ulur. Pada pita serapan sedang $2922.16-2852.72 \mathrm{~cm}^{-1}$ menunjukkan adanya gugus fungsi $\mathrm{CH}_{2}$ ulur, pada pita serapan lemah $1645.26 \mathrm{~cm}^{-}$ ${ }^{1}$ menunjukkan adanya gugus fungsi $\mathrm{C}=\mathrm{O}$, pada pita serapan sedang 1155.36 $1047.35 \mathrm{~cm}^{-1}$ menunjukkan adanya gugus fungsi C-O-C, dan pada pita serapan kuat dengan bilangan gelombang 873.75 menunjukkan masih adanya kandungan mineral silika.

Untuk membuktikan pembacaan pita serapan bilangan gelombang pada gugus fungsi kitosan hasil analisis FTIR dapat dilihat pada Tabel 1. Dari tabel pembacaan gugs fungsi kitosan tersebut, terlihat bahwa bilangan gelombang pada gugus fungsi yang diperoleh telah sesuai dengan literatur. Pita serapan gugus fungsi $\mathrm{OH}$ pada kitosan tahap 1,2 dan 3 dengan bilangan gelombang secara berturut-turut yaitu 3448,72., 3442,94., dan 3442.94 terjadi pelebaran. Hal ini disebabkan karena adanya gugus fungsi 
$\mathrm{N}-\mathrm{H}$ yang tumpang tindih dengan $\mathrm{O}-\mathrm{H}$. Gugus fungsi $\mathrm{C}=\mathrm{O}$ pada bilangan gelombang 1635,64 (kitosan 1 tahap) memiliki pita serapan sedang, yang menandakan bahwa gugus $\mathrm{C}=\mathrm{O}$ amida masih banyak dibandingkan dengan kitosan tahap 2 dan 3 yang memiliki pita serapan lemah pada bilangan gelombang 1645,26. Makin lemah pita serapan $C=0$ pada bilangan gelombang sekitaran 1640 maka gugus fungsi $\mathrm{C}=\mathrm{O}$ yang terdeasetilasi semakin banyak (Wiyarsi, 2011). Kusumahningsih menyatakan bahwa $\mathrm{N}-\mathrm{H}$ tekuk terdapat pada bilangn gelombang 1629,7. Tapi dalam penelitian yang dilakukan terlihat tidak nampak bilangan gelombang tersebut. Hal ini disebabkan karena terjadinya tumpang tindih dengan gugus fungsi $-\mathrm{CH}_{3}$ amida, yang ditandai dengan pelebaran pita serapan pada bilangan gelombang 1436,97., 1473,62., 1425,40. Terbukti bahwa metode yang digunakan dapat merubah kitin menjadi kitosan

Tabel 1. Pembacaan hasil analisis FTIR untuk semua kitosan

\begin{tabular}{|c|c|c|c|c|}
\hline \multirow{3}{*}{$\begin{array}{l}\text { Gugus } \\
\text { fungsi }\end{array}$} & \multicolumn{4}{|c|}{ Bilangan gelombang $\left(\mathrm{cm}^{-1}\right)$} \\
\hline & \multirow{2}{*}{$\begin{array}{c}\text { Literatur } \\
\text { (kusumaningsih, 2004) }\end{array}$} & \multicolumn{3}{|c|}{ Kitosan hasil penelitian } \\
\hline & & l tahap & 2 tahap & 3 tahap \\
\hline$-\mathrm{OH}$ ulur & 3452,3 & 3448,72 & 3442,94 & 3442,94 \\
\hline -C-O-ulur & 1039,6 & 1024,20 & $\begin{array}{l}1155,36- \\
1024,20\end{array}$ & $\begin{array}{l}1155,36- \\
1047,35\end{array}$ \\
\hline -C-H ulur & 2875,7 & 2924,09 & $\begin{array}{l}2922,16- \\
2852,72\end{array}$ & $\begin{array}{l}2922,16- \\
2852,72\end{array}$ \\
\hline$-\mathrm{CH}_{3}$ amida & 1473,5 & 1436,97 & 1473,62 & 1425,40 \\
\hline $\mathrm{C}=0$ ulur & 1647,1 & 1635,64 & 1645,26 & 1645,26 \\
\hline N-H tekuk & 1629,7 & $\begin{array}{c}\text { Tidak } \\
\text { nanpak }\end{array}$ & Tidak nanpak & Tidak nanpak \\
\hline $\begin{array}{l}\text { Mineral } \\
\text { silika }\end{array}$ & 873,7 & 873,75 & 869,90 & 873,75 \\
\hline
\end{tabular}

menggunakan alat spektroskopi FTIR. Derajaat deasetilasi dihitung menggunakan metode based line (garis dasar) menurut Domszy dan Roberts yaitu dengan mencatat puncak tertinggi dan mengukur pita dasar yang dipilih. Berdasarkan persamaan

yang dikemukakan oleh Domszy dan Roberts diperoleh derajat deasetilasi untuk waktu 1x3 jam, 2x3 jam dan 3x3 jam masingmasing sebesar $79 \%$, 85.9\%, dan $89.95 \%$.

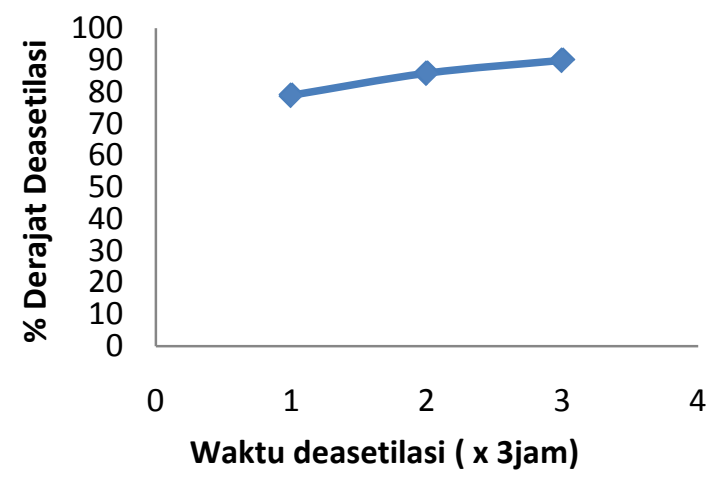

Gambar 4. Penambahan $\mathrm{NaOH}$ Secara Bertahap

Dari Gambar 4 memperlihatkan bahwa makin besar penambahan $\mathrm{NaOH}$ maka makin besar pula kenaikan derajat deasetilasi. Hal tersebut dikarenakan semakin banyak penambahan $\mathrm{NaOH}$ mengakibatkan semakin banyak pula gugus hidroksil yang tersedia untuk terjadinya proses hidrolisis, sehingga memperbesar kemungkinan terjadinya elimiasi pada gugus karbonil yang disebabkan tejadinya adisi oleh hidroksil, sehingga pembentukan amina juga semakin banyak. Penambahan $\mathrm{NaOH}$ yang dilakukan secara bertahap akan memberikan derajat deasetilasi yang besar karena reaktifitas $\mathrm{NaOH}$ yang semakin efektif disetiap penembahan $\mathrm{NaOH}$ (Junaidi dkk, 2009). Derajat 
deasetilasi maksimum diperoleh pada waktu 3x3 jam yaitu sebesar 89.95\%. Berdasarkan penelitian yang dilakukan oleh Junaidi dkk (2009) derajat deasetilasi maksimum pada kitosan yang berasal dari kulit udang diperoleh sebesar $84.16 \%$ dengan waktu 3x1 jam. Dalam penelitian ini diperoleh derajat deasetilasi yang lebih besar dari penelitian sebelumnya, hal ini kemungkinan disebabkan karena waktu yang digunakan disetiap penambahan $\mathrm{NaOH}$ yang baru lebih lama sehingga waktu deasetilasi kitin juga semakin lama.

\section{KESIMPULAN}

Kesimpulan yang dapat diperoleh dalam penelitian ini adalah:

1) Penambahan $\mathrm{NaOH}$ secara bertahap berpengaruh tidak nyata terhadap peningkatan derajat deasetilasi.

2) Derajat deasetilasi tertinggi diperoleh pada penambahan $\mathrm{NaOH}$ dengan waktu 3x3 jam sebesar 89.95\%.

\section{DAFTAR PUSTAKA}

Arif A.R., Ischaidar., Natsir Hasnah., Dali Seniwati. 2013. Isolasi Kitin dari Limbah Udang Putih (Penaeus merguiensis) Secara Enzimatis.

Seminar Nasional Kimia. 2013,. Makassar. Hal. 10-16.

Direktorat Jendral Perikanan Tangkap. 2012. Statistik Perikanan Tangkap Indonesia 2011. Jakarta: Kementrian Kelautan dan Perikanan.
Dinas Perikanan dan Kelautan Provinsi Riau. 2012. Statistic Perikanan Tangkap Provinsi Riau. Pekanbaru: Dinas Kelautan dan Perikanan.

Junaidi AB, Kartini I, Rusdiarso B. 2009. Chitosan Preparation With Multistage Deacetylation of Chitin and Investigation of its Physycochemical Properties. Indo. J. Chem. 9(3):369372.

Prasetyo, K.W. 2004. Khitosan, Pengendali Rayap Ramah Lingkungan. Bogor: LIPI.

Ramadhan, L.O.A.N, Radiman CL, Wahyuningrum D, Suendo V, Ahmad LO, Valiyaavetil S. 2010. Deasetilasi Kitin Secara Bertahap Dan Pengaruhnya Terhadap Derajat Deasetilasi Serta Massa Molekul Kitosan. Jurnal Kimia Indonesia. 5(1):17-21.

Sinardi, Soewondo prayatni, Notodarmojo Suprihanto. 2013. Pembuatan, Karakterisasi dan Aplikasi Kitosan dari Cangkang Kerang Hijau (Mytulus Verdis Linneaus) Sebagai Koagulan Penjernih Air. KoNTekS 7. 24-26 Oktober 2013, Kampus Universitas Sebelas Maret (UNS).

Wiyarsi A dan Priyambodo E. 2011. Pengaruh Konsentrasi Kitosan dari Cangkang Udang Terhadap Efesiensi Penjerapan Logam Berat. [Skripsi]. Yogyakarta: Jurusan Kimia FMIPA UNY. 